\title{
Development of Company's Management Framework on the Basis of Value Chain
}

\author{
Submitted 06/01/19, 1st revision 27/02/19, 2nd revision 25/03/19, accepted 30/05/19
}

\author{
A.P. Barsukov ${ }^{1}$, N.V. Bukhov ${ }^{2}$
}

\begin{abstract}
:
Purpose: To achieve the highest performance, manufacturers tend to transform their management frameworks and develop growth strategies. Utilizing the value chain concept authors analyzed the elements of value chain in the context of fast moving consumer goods (FMCG) environment.

Design/Methodology/Approach: The study involves outputs of two expert surveys generating the Osterwalder's pattern as well as modelling the omnichannel environment and three basic standpoints - FMCG frameworks. Key success factors and their strength were evaluated.

Findings: The results of the study form the methodological basis for improving the efficiency of management of trade companies. The findings indicate a certain similarity of the structure of the standard FMCG implementation systems selected by experts from distributor warehouses with the participation of structured retail and the implementation of standard FMCG through unstructured retail. At the same time, the business model used in the implementation of emotional FMCG with minimal participation of structured retail differs from the two similar options mentioned above in almost all parameters, excluding key activities.

Practical implications: Recommendations on the structure of management systems (including the specifics of business models) could be used by manufacturers in the formation of value chains involving the three emerging branches of retail trade in consumer goods.

Originality/Value: The structure of value chains based of key success factors on three emerging markets, as well as the features of values chains' management systems were first described.
\end{abstract}

Keywords: Value chains, consumers, key success factors, retail, family budget.

JEL Codes: D40, L10, L20.

Paper type: Research article in Special Issue dedicated to Russian Economy.

Section 3: Management Systems.

\footnotetext{
${ }^{1}$ Postgraduate, Department of General and Strategic Management, Rostov State University of Economics, Rostov-on-Don, Russian Federation.

${ }^{2}$ Postgraduate, Department of Business Analysis and Forecasting, Rostov State University of Economics, Rostov-on-Don, Russian Federation, bnvscience@gmail.com
} 


\section{Introduction}

Management transforms the company's management framework, seeking to achieve its goals more effectively (Bautin et al., 2008; Burton and Obel, 1984; Baligh et al., 1996; Raisch, 2008) in conditions of alterations in the business environment (Daft and Lewin, 1993). The functional aspects of a company's activities, aimed at the implementation of a certain strategy, could be described based on a set of variables developed by specialists (Andersen and Jonsson, 2006; Robbins, 1990; Shetty, 1979; Nash, 1983; Walton and Dawson, 2001; Hambrick, 1983) representing the specialization and formalization of employees, the centralization of basic decisions' formulation, the range of functions implemented by staff and the profitability of the organization. At the same time, the diversity of staff activities, the inclusion of various functional units into the organizational framework of a company and distribution of functions between them are described based on the use of the horizontal differentiation parameter (the "specialization" variable); the vertical differentiation parameter (another element of the specialization variable) represents the number of levels in the formed management pyramid. As one of the reference points in the formation of the management framework, authors considered the value chain concept (VC) developed by Porter $(1980 ; 1985 ; 2005)$, as well as its various modifications developed by other specialists (Walas-Trebacz, 2015). This concept could be utilized by the company - organizer of VC (Yuldasheva et al., 2013) in order to form a system for managing the interaction of partner companies (Trefilova and Prokoptsov, 2015; Yuldasheva et al., 2013: Polyakova et al., 2019).

Retail trade (including FMCG retail trade) closes the VCs and includes manufacturers, distributors, transport and retail companies (Koval and Savostina, 2006) and becomes an attractive object for studying the processes of formation and transformation of VCs. Russian retail systems grow rapidly and repeat the key transformation stages that the industry has undergone in Western countries (Arzumanova, 2011; Gorskaya, 2011; Kalinina, 2006; Koval and Savostina, 2006; Kalashnikova, 2016; Sovizdranyuk and Chigidin, 2016; Znatov, 2007; Bukhtiyarova and Pavlenko, 2012; Naplekova, 2012).

We proceed from an important role of two following factors in the evolution of retail: the evolution of the service provided to customers and the evolution of technology. We note therewith that the demand for new types of services (generated through modern technologies) is progressing as the family budget (FB) grows (a part of the family's expenses for essential items (per month)) (Barsukov, 2018). With a significant increase in FB, an individualization (focusing on personal approach) and saving time become dominant among the actual expectations of a significant part of customers. The use of modern information technologies (transforming into the main drivers of evolution) allows accelerating the processes of selection and delivery of goods through the centralized collection/processing of information, individualization/personalization of offers, etc. Through the modern information technologies, supplier companies will be able to quickly transform the structure of 
their $\mathrm{VC}$, bringing them in line with the updated expectations of target customer groups, and partner companies. The main stages of the expected changes are shown in Figure 1. The proposed changes will affect distribution and retail. Some of their functions will be transferred to manufacturers. The gradual formation of the following basic elements of distribution transformation is expected:

- the main functionality of distributors is digitized and could be transferred to manufacturers; logistics becomes the only significant area of activity of distributors; - the use of digitized tools will reduce the manufacturer's costs and increase the level of controllability of goods flow.

Figure 1. VC and consumer market transformation stages (Developed by authors)

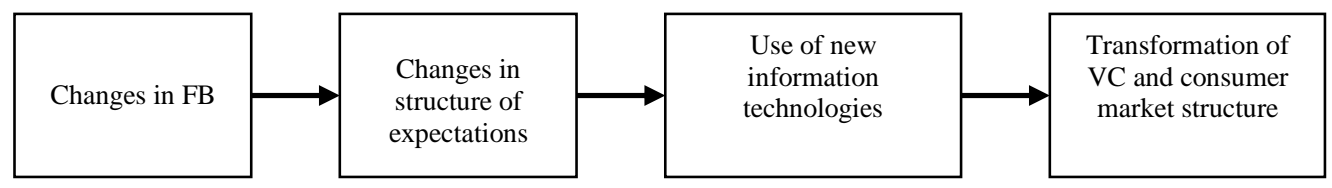

Retail will be also spitted into two main branches:

- routine goods, most of which will be promoted through the internet (large networks), the trade stocks will be sold via unstructured (not included in large networks) retail;

- 'emotionally significant' product (making a decision about buying involves direct customer contact with the product, or the selection process itself creates positive emotions from the buyer) will be implemented through eFMCG retail stores (emotional FMCG).

Moreover, based on online platforms, an omni-channel environment will be formed, which includes not only the sale of goods, but also services, in particular, financial ones, which will provide the creation of integrated service whose characteristics will be transformed in accordance with individual consumer expectations. The development of offers and services' personalization will contribute to the transformation of omnichannel platforms into personal (electronic) assistants, recommending the best product for each customer.

Notable that the omni-channel environment is created by companies with the largest amounts of information about customers, as well as the best technological capabilities to receive and process this data (Barsukov, 2017). A transformation of the interaction of manufacturers with distributors is pending. The utilization of modern technologies allows for collecting orders centrally and making orders for goods by manufacturing companies (which come from different customers), assessing the level of solvency of counterparties, remotely controlling the activity of outlets. As a result, only logistics remains in the real responsibility area of distributors. The intensive development of logistics will allow a number of 
companies to survive, the rest will be forced to change their business profile. We consider notable the development of management frameworks for emerging VC, including the features of the business models being created for their performance in three FMCG implementation areas briefly described above.

The study was carried out to analyze the feasibility of utilizing various approaches to the distribution of functions within business models that will be used by manufacturing companies when dealing with structured retail, unstructured retail and in the implementation of eFMCG.

\section{Methods of Study}

Two expert surveys (ES-1 and ES2) were conducted. When studying the structure of promising business models (as part of ES-1), the pattern used by Osterwalder (2005; 2010) and the corresponding questionnaire were utilized. Functional distribution projects were studied using a modified method proposed by modern authors (Anderssen and Jonsson, 2006) implemented as part of ES-2. The strength of the KSF (key success factors) was calculated using the method proposed by domestic authors (Dimitriadi and Karasev, 2015)

\section{Results and Discussion}

The obtained results indicate a certain similarity of the structure of the standard FMCG implementation systems selected by experts from distributor warehouses with the participation of structured retail $(F M C G+S R)$ and the implementation of standard FMCG through unstructured retail (FMCG + USR). This similarity concerns the structure of planned business models, goals and strategic guidelines and functional content of companies, as well as the level of centralization of key decisions (Tables 1-10). At the same time, the business model (BM) used in the implementation of emotional FMCG (eFMCG) with minimal participation of structured retail (Table 2) differs from the two similar options mentioned above (Table 1) in almost all parameters, excluding Key activities (Market Research), Key Resources (Production Technologies), Value Proposal (Quality) and Structure of Income (Margin). The goals and strategic orientations of the business are also significantly different (Table 3). Certain differences in the structure of the KSF (Tables 4-6) are also applied.

Table 1. Structure of business model oriented at implementation of FMCG+SR and FMCG+USR (developed by authors)

\begin{tabular}{|l|l|l|l|l|}
\hline $\begin{array}{l}\text { Key } \\
\text { partners }\end{array}$ & Key activities & $\begin{array}{l}\text { Value proposal } \\
\text { values) }\end{array}$ & $\begin{array}{l}\text { (key } \\
\text { Customer relation } \\
\text { technologies }\end{array}$ & $\begin{array}{l}\text { Target customen } \\
\text { groups }\end{array}$ \\
\hline $\begin{array}{l}\text { Online } \\
\text { offline } \\
\text { retailers }\end{array}$ & + Production & Quality & Surveys & Mass segment \\
\cline { 2 - 5 } & Sales & Low price & & \\
\cline { 2 - 4 } & & & \\
\hline
\end{tabular}




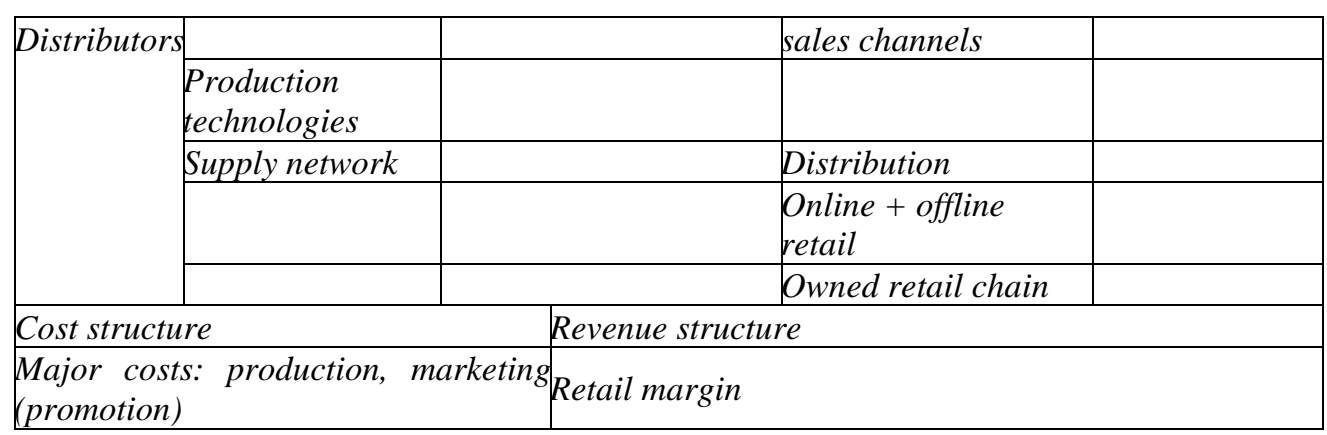

The distribution of functions between departments is shown in Tables 2-8, the differences in the level of centralization of management are reflected in Tables 9-10.

Table 2. Structure of business model oriented at implementation of eFMCG (developed by authors)

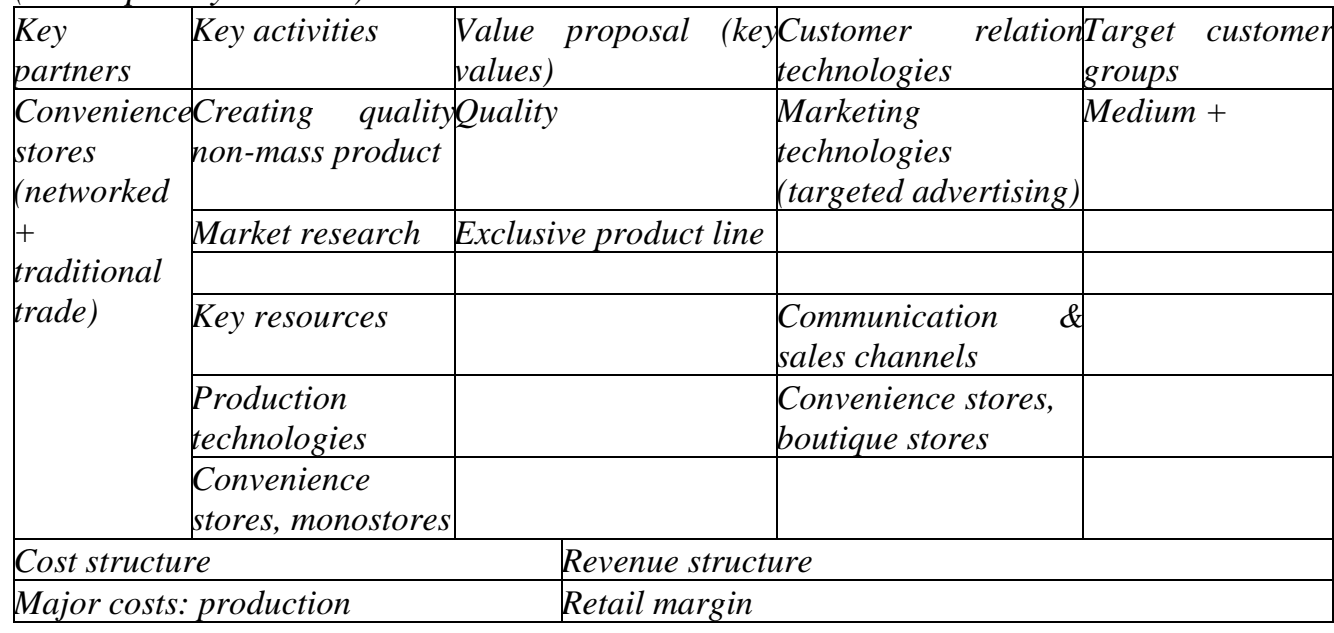

Table 3. Goals and strategic benchmarks of trade types under analysis (developed by authors)

\begin{tabular}{l|l} 
Trade type & Goal statement / strategy description
\end{tabular}

Implementation of standard FMCGQuality and demanded product

from distributors' warehouses with Large-scale production of standard goods;

the participation of structured retail- Efficient production with minimal costs;

- Market domination due to the price and quality.

Quality and demanded product

Implementation of standard FMCG. Large-scale production of standard goods;

via unstructured retail $\quad$ Efficient production with minimal costs;

- Market domination due to the price and quality.

Quality, non-standard product

Implementation of emotional Non-standard product (no competition with branded FMCG with minimal participationproducts);

of structured retail

- High quality; 
Low production volumes;

- Market leads (innovations)

Table 4. Strength of KSF - implementation of FMCG+SR (developed by authors)

\begin{tabular}{|c|c|c|c|c|c|c|}
\hline \begin{tabular}{|l|} 
Groups of \\
market \\
participants
\end{tabular} & flmpact & Expectations & $\begin{array}{l}\text { Significance } \\
\text { of } \\
\text { expectations }\end{array}$ & $\begin{array}{l}\text { KSF } \\
\text { strengtl }\end{array}$ & $\begin{array}{l}\text { KSF } \\
\text { hstrength } \\
\text { rank }\end{array}$ & $\begin{array}{l}\text { KSF strength } \\
\text { rank (with no } \\
\text { manufacturer's } \\
\text { expectations) }\end{array}$ \\
\hline \multirow{4}{*}{ Manufacturer } & & Product share* & 0,4 & 1,6 & 2 & \\
\hline & & Consumer loyalty & 0,1 & 0,4 & 11 & \\
\hline & & Coverage** & 0,3 & 1,2 & 6 & \\
\hline & & Turnover & 0,2 & 0,8 & 8 & \\
\hline \multirow{3}{*}{ Distributor } & \multirow{3}{*}{$\beta$} & Turnover & 0,4 & 1,2 & 4 & 3 \\
\hline & & Coverage $e^{* * *}$ & 0,2 & 0,6 & 9 & 4 \\
\hline & & Margin & 0,4 & 1,2 & 4 & 3 \\
\hline \multirow{3}{*}{ Retail } & \multirow{3}{*}{5} & Turnover & 0,6 & 3,0 & 1 & 1 \\
\hline & & Coverage $^{* * * * *}$ & 0,3 & 1,5 & 3 & 2 \\
\hline & & Consumer loyalty & 0,1 & 0,5 & 10 & 5 \\
\hline \multirow{4}{*}{ Consumer } & \multirow{4}{*}{2} & Product line & 0,2 & 0,4 & 11 & 6 \\
\hline & & Price & 0,6 & 1,2 & 6 & 3 \\
\hline & & Convenience & 0,1 & 0,2 & 13 & 7 \\
\hline & & Quality & 0,1 & 0,2 & 13 & 7 \\
\hline
\end{tabular}

* \% share of goods in total sales;

** max. number of distribution points offering goods;

*** exposure in distribution points;

****max. number of distribution points as per consumers' capacity (FB).

Table 5. Strength of KSF - implementation of FMCG+USR (developed by authors)

\begin{tabular}{|c|c|c|c|c|c|c|}
\hline \begin{tabular}{|l|} 
Groups of \\
market \\
participants
\end{tabular} & $\begin{array}{l}\text { flmpact } \\
\text { level }\end{array}$ & Expectations & $\begin{array}{l}\text { Significance } \\
\text { of } \\
\text { expectations }\end{array}$ & $\begin{array}{l}\mathrm{KSF} \\
\text { strength }\end{array}$ & $\begin{array}{l}\text { KSF } \\
\text { strength } \\
\text { rank }\end{array}$ & $\begin{array}{l}\text { KSF strength } \\
\text { rank (with no } \\
\text { manufacturer's } \\
\text { expectations) }\end{array}$ \\
\hline \multirow{4}{*}{ Manufacturer } & \multirow{4}{*}{3} & Product share & 0,4 & 1,2 & 6 & \\
\hline & & Consumer loyalty & 0,1 & 0,3 & 11 & \\
\hline & & Coverage & 0,2 & 0,6 & 9 & \\
\hline & & Turnover & 0,3 & 0,9 & 7 & \\
\hline \multirow{3}{*}{ Distributor } & \multirow{3}{*}{4} & Turnover & 0,4 & 1,6 & 2 & 2 \\
\hline & & Coverage & 0,2 & 0,8 & 8 & 6 \\
\hline & & Margin & 0,4 & 1,6 & 2 & 2 \\
\hline \multirow{3}{*}{ Retail } & \multirow{3}{*}{5} & Turnover & 0,6 & 3,0 & 1 & 1 \\
\hline & & Coverage & 0,1 & 0,5 & 10 & 7 \\
\hline & & Consumer loyalty & 0,3 & 1,5 & 5 & 5 \\
\hline \multirow{3}{*}{ Consumer } & \multirow{3}{*}{2} & Product line & 0,1 & 0,2 & 12 & 8 \\
\hline & & Price & 0,8 & 1,6 & 2 & 2 \\
\hline & & Convenience & 0,1 & 0,2 & 12 & 8 \\
\hline
\end{tabular}


Table 6. Strength of KSF - implementation of eFMCG(developed by authors)

\begin{tabular}{|c|c|c|c|c|c|c|}
\hline $\begin{array}{l}\text { Groups of } \\
\text { market } \\
\text { participants }\end{array}$ & flmpact & Expectations & $\begin{array}{l}\text { Significance } \\
\text { of } \\
\text { expectations }\end{array}$ & \begin{tabular}{|l|} 
KSF \\
strength
\end{tabular} & $\begin{array}{l}\text { KSF } \\
\text { strength } \\
\text { rank }\end{array}$ & $\begin{array}{l}\text { KSF strength rank } \\
\text { (with no } \\
\text { manufacturer's } \\
\text { expectations) }\end{array}$ \\
\hline \multirow{3}{*}{ Manufacturer } & & Quality & 0,4 & 2,0 & 2 & \\
\hline & & Consumer loyalty & 0,4 & 2,0 & 2 & \\
\hline & & Turnover & 0,2 & 1,0 & 7 & \\
\hline \multirow{3}{*}{ Distributor } & \multirow{3}{*}{1} & Turnover & 0,4 & 0,4 & 9 & 6 \\
\hline & & Coverage & 0,2 & 0,2 & 13 & 10 \\
\hline & & Margin & 0,4 & 0,4 & 9 & 6 \\
\hline \multirow{3}{*}{ Retail } & \multirow{3}{*}{$\beta$} & Turnover & 0,6 & 1,8 & 4 & 2 \\
\hline & & Coverage & 0,3 & 0,9 & 8 & 5 \\
\hline & & Consumer loyalty & 0,1 & 0,3 & 12 & 9 \\
\hline \multirow[t]{2}{*}{ Associate } & & Consumer loyalty & 0,6 & 2,4 & 1 & 1 \\
\hline & 4 & Turnover & 0,4 & 1,6 & 5 & 3 \\
\hline \multirow{3}{*}{ Consumer } & \multirow{3}{*}{2} & Product line & 0,2 & 0,4 & 9 & 6 \\
\hline & & Price & 0,1 & 0,2 & 13 & 10 \\
\hline & & Quality & 0,7 & 1,4 & 6 & 4 \\
\hline
\end{tabular}

Table 7. Organizational design / functional breakdown under FMCG+SR and FMCG+USR (developed by authors)

\begin{tabular}{|c|c|c|c|c|c|c|}
\hline \multirow[b]{2}{*}{ Functions } & \multicolumn{6}{|c|}{ Departments } \\
\hline & Marketing & Finance & Sales & Logistics & Production & Procurements \\
\hline 1. Planning & $\mathbf{x}$ & $\mathbf{x}$ & & & $\mathbf{x}$ & $\mathbf{x}$ \\
\hline 2. Sales & & & $\mathbf{x}$ & & & \\
\hline 3. Production & & & & & & \\
\hline 4. Market research & $\mathbf{x}$ & & & & & \\
\hline \begin{tabular}{|l|}
5. \\
generation
\end{tabular} & $\mathrm{d} \mathbf{x}$ & & & & & \\
\hline 6. Sales promotion & $\mathbf{x}$ & & & & & \\
\hline 7. Budgeting & & $\mathbf{x}$ & & & & \\
\hline 8. Pricing & $\mathbf{x}$ & & $\mathbf{x}$ & & & \\
\hline 9. Delivery & & & & $\mathbf{x}$ & & \\
\hline \begin{tabular}{|l|l|}
$10 . \quad$ Care \& \& \\
servicing
\end{tabular} & & & $\mathbf{x}$ & & & \\
\hline
\end{tabular}

Table 8. Organizational design / functional breakdown under eFMCG (developed by authors)

\begin{tabular}{|l|l|l|l|l|l|l|}
\hline \multirow{2}{*}{ Functions } & \multicolumn{5}{l|}{ Departments } & \multicolumn{5}{l|}{} \\
\cline { 2 - 7 } & Marketing & Finance & Sales & Logistics & Production & Procurements \\
\hline 1. Planning & & & $\mathbf{x}$ & & $\mathbf{x}$ & $\mathbf{x}$ \\
\hline 2. Sales & & & $\mathbf{x}$ & & & \\
\hline 3. Production & & & & & $\mathbf{x}$ & \\
\hline 4. Market research & & & $\mathbf{x}$ & & & \\
\hline
\end{tabular}




\begin{tabular}{|l|l|l|l|l|l|l|}
\hline $\begin{array}{l}\text { 5. Demand } \\
\text { generation }\end{array}$ & & $\mathbf{x}$ & & & \\
\hline 6. Sales promotion & & & $\mathbf{x}$ & & & \\
\hline 7. Budgeting & & $\mathbf{x}$ & & & & \\
\hline 8. Pricing & & $\mathbf{x}$ & & & & \\
\hline 9. Delivery & & & & $\mathbf{x}$ & & \\
\hline $\begin{array}{l}\text { 10. Care \& } \\
\text { servicing }\end{array}$ & & & $\mathbf{x}$ & & & \\
\hline
\end{tabular}

Table 9. Centralization / decentralization of management under FMCG+SR and FMCG+USR (developed by authors)

\begin{tabular}{|c|c|c|c|c|c|}
\hline \multirow[b]{2}{*}{ Activities } & \multicolumn{5}{|c|}{ Decision level } \\
\hline & CEO & Director & $\begin{array}{l}\text { Departmen } \\
\text { manager }\end{array}$ & $\begin{array}{l}\text { tine } \\
\text { manager }\end{array}$ & $\begin{array}{l}\text { Employee } \\
\text { (individually) }\end{array}$ \\
\hline 1 & 2 & 3 & 4 & 5 & 6 \\
\hline Department headcount & $\mathbf{x}$ & $\mathbf{x}$ & & & \\
\hline Recruiting & $\mathbf{x}$ & $\mathbf{x}$ & $\mathbf{x}$ & $\mathbf{x}$ & \\
\hline Resolving internal labor disputes & & & $\mathbf{x}$ & $\mathbf{x}$ & \\
\hline Overtime & & & $\mathbf{x}$ & $\mathbf{x}$ & \\
\hline Supply schedule \& orders' priority & & & $\mathbf{x}$ & $\mathbf{x}$ & \\
\hline Production schedule & $\mathbf{x}$ & $\mathbf{x}$ & $\mathbf{x}$ & & \\
\hline Dismissal & $\mathbf{x}$ & $\mathbf{x}$ & $\mathbf{x}$ & $\mathbf{x}$ & \\
\hline Recruiting methods & & $\mathbf{x}$ & $\mathbf{x}$ & $\mathbf{x}$ & \\
\hline Job execution methods & & $\mathbf{x}$ & $\mathbf{x}$ & $\mathbf{x}$ & \\
\hline Equipment utilization & & & $\mathbf{x}$ & $\mathbf{x}$ & $\mathbf{x}$ \\
\hline Tasks breakdown & $\mathbf{x}$ & $\mathbf{x}$ & $\mathbf{x}$ & $\mathbf{x}$ & \\
\hline
\end{tabular}

Table 10. Centralization / decentralization of management under eFMCG (developed by authors)

\begin{tabular}{|l|l|l|l|l|l|}
\hline \multirow{2}{*}{ Activities } & \multicolumn{3}{|l|}{ Decision level } & \multicolumn{2}{l|}{} \\
\cline { 2 - 6 } & CEO & Director & $\begin{array}{l}\text { Department } \\
\text { manager }\end{array}$ & Line manager & $\begin{array}{l}\text { Employee } \\
\text { (individually) }\end{array}$ \\
\hline Department headcount & & $\mathbf{x}$ & & & \\
\hline Recruiting labor & & $\mathbf{x}$ & & & \\
\hline $\begin{array}{l}\text { Resolving internal } \\
\text { disputes }\end{array}$ & & $\mathbf{x}$ & & & \\
\hline Overtime & & $\mathbf{x}$ & & & \\
\hline $\begin{array}{l}\text { Supply schedule \& orders } \\
\text { priority }\end{array}$ & & $\mathbf{x}$ & & & \\
\hline Production schedule & & $\mathbf{x}$ & & & \\
\hline Dismissal & & $\mathbf{x}$ & & & \\
\hline Recruiting methods & & $\mathbf{x}$ & & & \\
\hline Job execution methods & & $\mathbf{x}$ & & & \\
\hline Equipment utilization & & $\mathbf{x}$ & & & \\
\hline Tasks breakdown & & $\mathbf{x}$ & & & \\
\hline
\end{tabular}


We note that designing the functional breakdown in order to create a company capable of efficiently implementing a range of specific functions, compared with the management's desire to distribute functions within an established organizational structure, provides more opportunities for the implementation of the strategy developed by the management. When forming the basis for implementing the functions stipulated by the strategy, the management utilizes the technique proposed by Fayol (1949), Fayol et al. (2012), Burtseva and Chernyavskaya (2016). We also note that when choosing strategies, the management should rely upon resources available (Grant, 2008; Katkalo, 2011), which will be distributed among functional departments. The authors proposed a structure of stage actions aimed at creating / transforming the management system (Figure 2). The elements associated with the development of VC focused on the most powerful KSF are shown in italics.

To determine the key benchmarks in the formation of three trade types' management frameworks (FMCG + SR, FMCG + USR and eFMCG), the values of the corresponding KSF were analyzed to identify the most significant ones. When managing the implementation of FMCG + SR for a manufacturer with high impact equal to 4 points (according to table 4), main benchmarks are meeting the expectations of the following KSF participants:

- retail: providing turnover and coverage;

- distributor: ensuring turnover and expected margin.

Figure 2. Key stages of management framework's transformation (developed by authors)

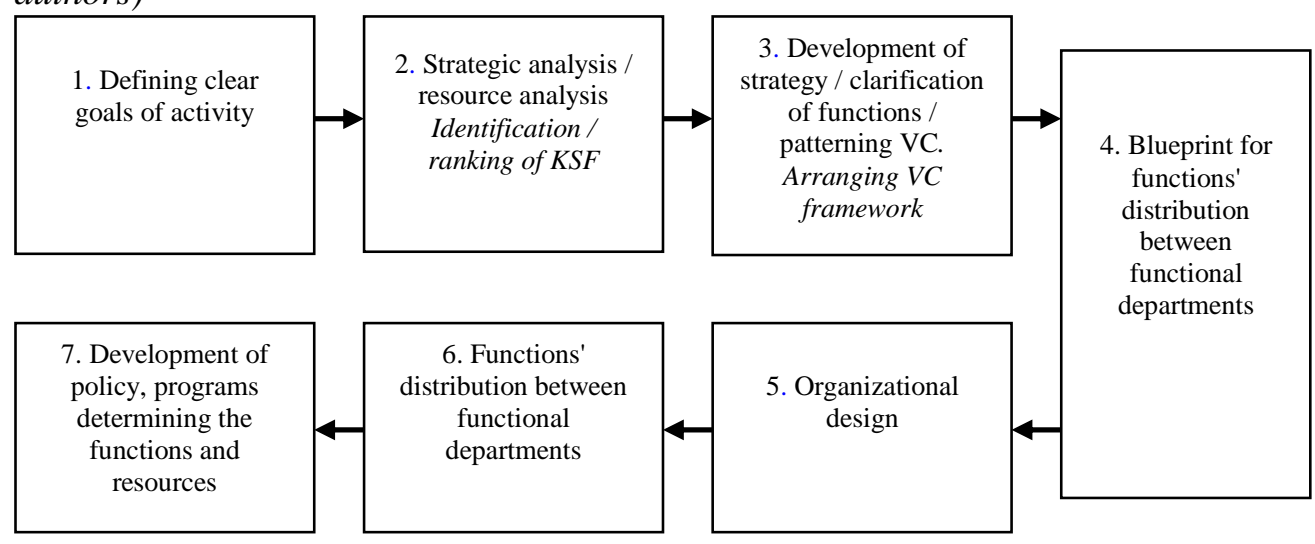

Meeting the expectations of these VC links encourages them to act to meet the expectations of the end user (i.e. the desired price (the KSF strength is 6). We note that in the implementation of FMCG $+\mathrm{SR}$, the role of retail networks is more significant than distributors' one. To ensure effective management of VC of FMCG $+\mathrm{SR}$ and the achievement of its expectations, first, of the product share (strength is 2) and the coverage (strength is 6), the manufacturer needs to enable a number of actions as follows: 
- ensure solid supply to increase the retail turnover, which relates to the organization of logistics;

- form proposals for retailers for the development of new outlets using omnichannel environment to achieve the desired retail coverage;

- provide a full range of marketable product for distributors to increase the turnover;

- create a discount system to obtain the desired distributors' margin.

The key elements of the VC management framework of FMCG + SR and the distribution of functions between departments are presented in Table 11, which is based on the analysis of Table 4 and 7 data. The main benchmarks for the manufacturer for the FMCG + SR (in the context of impact on sales at the level of 3 points, Table 5) are as follows:

- distributor: ensuring turnover and expected margin;

- retail: ensuring turnover and consumer loyalty.

Table 11. Elements of the FMCG+SR management framework (developed by authors)

\begin{tabular}{|c|c|c|c|c|}
\hline $\begin{array}{l}\text { Market } \\
\text { actors }\end{array}$ & $\mathrm{KSF}$ & Manufacturer's actions & \begin{tabular}{|l|} 
Functions \\
implemented
\end{tabular} & Department \\
\hline \multirow[b]{2}{*}{ Retail } & turnover & $\begin{array}{l}\text { prompt delivery of the demanded products to } \\
\text { the distributor }\end{array}$ & Delivery & Logistics \\
\hline & coverage & $\begin{array}{l}\text { formation of proposals for the development } \\
\text { of retail points in line with the results of the } \\
\text { analysis of consumers from the omnichannel } \\
\text { environment }\end{array}$ & $\begin{array}{l}\text { Market } \\
\text { Research }\end{array}$ & Marketing \\
\hline \multirow{2}{*}{ Distributor } & turnover & $\begin{array}{l}\text { prompt delivery of complete product line as } \\
\text { needed }\end{array}$ & ${ }^{\mathrm{S}}$ Delivery & Logistics \\
\hline & margin & providing discounts & Pricing & $\begin{array}{l}\text { Marketing, } \\
\text { Finance }\end{array}$ \\
\hline
\end{tabular}

Meeting the expectations of these VC links encourages them to gain traction for reaching the consumer's desired price (KSF strength is 2). Plus, the price factor for the consumer in the FMCG + USR framework is more significant than the one in $\mathrm{FMCG}+\mathrm{SR}$. The role of distributors in the considered VC is more significant than their role in the FMCG $+\mathrm{SR}$. The producer's expectations structure in the FMCG + USR is slightly different from its expectations in the FMCG + SR framework. In the FMCG + SR, KSFs like product share and coverage are important for the manufacturer, but in the FMCG + USR framework, the manufacturer seeks to ensure, mainly, product share and turnover. Coverage there is not a significant factor, since in this case the distributor realizes this function.

In order to ensure the effective management of the FMCG + USR implementation, the manufacturer should: 
- perform the actions recommended for dealing with FMCG + SR to meet the expectations of retail and distributors;

- use the opportunities of the omnichannel environment and implement programs aimed at attracting customers to ensure consumer loyalty for the retail.

Table 12 uses the data generated through the analysis of Tables 5 and 7 and indicates the elements of the FMCG + USR framework and the distribution of functions between the departments of the manufacturer.

Table 12. Elements of the FMCG+USR management framework (developed by authors)

\begin{tabular}{|l|l|l|l|l|}
\hline $\begin{array}{l}\text { Market } \\
\text { actors }\end{array}$ & KSF & Manufacturer's actions & $\begin{array}{l}\text { Functions } \\
\text { implemented }\end{array}$ & Department \\
\hline \multirow{3}{*}{ Retail } & turnover & prompt delivery of demanded products & Delivery & Logistics \\
\cline { 2 - 5 } & $\begin{array}{l}\text { consumer } \\
\text { loyalty }\end{array}$ & $\begin{array}{l}\text { surveying consumer preferences through } \\
\text { omnichannel environment; } \\
\text { advertising; } \\
\text { offers; } \\
\text { developing consumer loyalty programs. }\end{array}$ & $\begin{array}{l}\text { Market } \\
\text { research, } \\
\text { ales } \\
\text { promotion }\end{array}$ & Marketing \\
\hline Distributor & turnover & $\begin{array}{l}\text { prompt delivery of complete product line } \\
\text { as needed }\end{array}$ & Delivery & Logistics \\
\hline margin & providing discounts & Pricing & $\begin{array}{l}\text { Marketing, } \\
\text { Sales }\end{array}$ \\
\hline
\end{tabular}

A comparison of the functions implemented by departments in the FMCG $+\mathrm{SR}$ and FMCG + USR frameworks indicates that:

- in the FMCG + USR, the role of the marketing department significantly increases;

- the functional content of the logistics departments' activities for both management frameworks is identical.

The analysis of the KSF strength of the eFMCG indicates that for a manufacturing company with the highest level of impact (5 points according to Table 6 ) on the sales volumes, the most significant in developing the eFMCG is meeting the following expectations of VC links:

- associate: ensuring consumer loyalty;

- retail: provision of turnover and coverage.

It should be noted that:

- the strength rankings of the manufacturer's KSF (quality and consumer loyalty) are of high values (2);

- significant consumer expectations of the eFMCG are not connected with the price (as shown by the analysis of the structure of FMCG + SR and FMCG + USR), but with the quality (specificity) of non-standard products; 
- Distributor expectations' factors for the eFMCG are not significant (their KSF ranks are low).

To implement the eFMCG, the manufacturer should:

- perform actions similar to those in the FMCG + USR to increase the turnover of retail and to achieve the desired coverage;

- conduct in-depth marketing research on the demand, develop and carry out activities to attract consumers to ensure the turnover and customer loyalty, using the omnichannel environment.

Table 13 is formed on the basis of Tables 6 and 8 and clarifies the eFMCG framework and the distribution of functions between departments of the manufacturer.

Table 13. Elements of the eFMCG management framework (developed by authors)

\begin{tabular}{|c|c|c|c|c|}
\hline $\begin{array}{l}\text { Market } \\
\text { actors }\end{array}$ & KSF & Manufacturer's actions & $\begin{array}{l}\text { Functions } \\
\text { implemented }\end{array}$ & Department \\
\hline \multirow[t]{2}{*}{ Associate } & $\begin{array}{l}\text { consumer } \\
\text { loyalty }\end{array}$ & $\begin{array}{l}\text { surveying consumer preferences through } \\
\text { omnichannel environment; } \\
\text { advertising campaigns; } \\
\text { conducting promotions; } \\
\text { development of consumer loyalty } \\
\text { programs. }\end{array}$ & $\begin{array}{l}\text { in-depth market } \\
\text { research, } \\
\text { sales promotion, } \\
\text { demand generation, } \\
\text { planning }\end{array}$ & \\
\hline & turnover & prompt delivery of demanded products & delivery & logistics \\
\hline \multirow[b]{2}{*}{ Retail } & turnover & prompt delivery of demanded products & delivery & logistics \\
\hline & coverage & $\begin{array}{l}\text { proposals for the development of retail } \\
\text { points in accordance with the results of } \\
\text { the analysis of consumers from the } \\
\text { omnichannel environment }\end{array}$ & & sales \\
\hline
\end{tabular}

Notable that companies producing eFMCG goods are often small. Therefore, many functions are distributed among the minimum number of departments included in the organizational framework. In particular, market research is most often carried out by the sales department, the director makes almost all major decisions concerning the management of the company.

Thus, a comparative analysis of Tables 11-13 indicates that:

- when implementing FMCG + SR and FMCG + USR frameworks, the price for a standard product is an important success factor for the consumer, and when implementing the eFMCG, the key success factor is the quality / specificity of a non-standard product;

- manufacturer's expectations are different:

- the product share and coverage - in the FMCG + SR;

- the product share and turnover - in the FMCG + USR; 
- the quality and consumer loyalty - in the eFMCG;

- the role of the functions of the logistics department is insignificant in the FMCG + SR and FMCG + USR, and it is completely unimportant in the eFMCG;

- the role of the marketing functional is different as follows:

- insignificant - in the FMCG + SR;

- more significant - in the FMCG + USR;

- significant - in the eFMCG (mainly related to market research; is delegated to the sales department).

\section{References:}

Andersen, J.A., Jonsson, P. 2006. Does the organization structure matter? On the relationship between structure, functioning and effectiveness. International Journal of Innovation and Technology Management, 2(3), 237-263.

Arzumanova, T.I. 2011. Economics and planning in trade and catering. Moscow, Dashkov and Co., 272.

Baligh, H.H., Burton, R.M., Obel, B. 1996. Organizational consultant: Creating a useable theory for organizational design. Management Science, 42, 1648-1662.

Barsukov, A.P. 2017. Transformation of value chains: mechanisms and perspectives. Economics and Business, 1203 (89-3), 840-849.

Barsukov, A.P. 2017. Value chain formation: identification of key target groups. Humanities and Socio-Economic Sciences, 3(94), 98-105.

Barsukov, A.P. 2018. Transformation of the value chain: the basic mechanisms and unused opportunities. Management of Economic Systems: electronic scientific journal, 4 (11), 4.

Bautin, V.M., Kuscheva, E.A., Shatalov, M.A., Morozov, A.N. 2008. Formation of effective organizational and management frameworks of large enterprises. Bulletin of Belgorod University of Consumer Cooperation, 3, 31-34.

Buhtiyarova, T.I., Pavlenko, E.L. 2012. Consumer market of the region: state, trends and development prospects. Agribusiness: Regions of Russia, 8, 1-7.

Burton, R.M., Obel, B. 1984. Designing efficient organizations. Modeling and experimentation. North Holland, Amsterdam.

Burtseva, M.N., Chernyavskaya, A.R. 2016. The relationship of management functions. Economic Environment, 2(16), 68-70.

Daft, R.L., Lewin, A.Y. 1993. Where are the forms for the "new" organizational forms? An editorial essay, Organizational Science, 4, 4.

Dimitriadi, N.A., Karasev, D.N. 2015. Identifying key success factors as the basis for developing a business strategy. International Scientific and Practical Conference: Mechanisms and Tools for the Economic Growth of the Regional Economy: State, Policy and Forecast, Rostov-on-Don, 23-33.

Fayol H., Emerson, G., Taylor, F., Ford, H. 2012. Management is a science and art. Moscow, INFRA-M, 36.

Fayol, H. 1949. General and industrial management. London, Sir Issac Pitman \& Sons, Ltd.

Gorskaya, Yu.A. 2011. The evolution of retail formats. Volga trade and economic journal, 1, 13-18.

Grant, R.M. 2008. Modern strategic analysis. SPb., Peter, 555.

Hambrick, D.C. 1983. Some tests of the strategic types. Academy of Management Journal, 26, 1, 5-26. 
Kalashnikova, I.V. 2016. The formation of network trading: the experience of Russian food retail. Legal, socio-humanitarian and economic problems in the focus of scientific research: proceedings of the All-Russian scientific-practical conference, Far Eastern State University of Communications, Khabarovsk, 133-141.

Kalinina, M. 2006. The Impact of the Development of a Retail-Wholesale Structure on Economic Indicators. Marketing, 2, 92-93.

Katkalo, V.S. 2011. The evolution of the theory of strategic management. St. Petersburg State University's High School of Management, 548.

Koval, I.V., Savostina, S.E. 2006. The creation of modern retail formats of the municipality. Bulletin of Pacific State University of Economics, 4(40), 3-12.

Naplekova, Yu.A. 2012. Multi-format as a factor in improving the efficiency of retail. Bulletin of the Belgorod University of Cooperation, Economics and Law, 2, 163-169.

Nash, M. 1983. Managing organizational performance. Jossey-Bass, San Francisco, CA.

Osterwalder, A., Pigneur, Y., Clark, T. 2010. Business Model Generation: A Handbook for Visionaries, Game Changers, and Challengers. Hoboken, NJ, Wiley.

Osterwalder, A., Pigneur, Y., Tucci, C. 2005. Clarifying business models: Origins, present and future of the concept. Communications of the Association for Information Science, 16, 1-25.

Porter, M. 1980. Competitive Strategy. New York, Free Press.

Porter, M. 1985. Competitive Advantage. New York, Free Press.

Porter, M. 2005. Competitive advantage: how to achieve high results and ensure its sustainability. Alpina Business Books, 715.

Polyakova, A.G., Loginov, M.P., Serebrennikova, A.I. \& Thalassinos, E.I. 2019. Design of a Socio-Economic Processes Monitoring System Based on Network Analysis and Big Data. International Journal of Economics \& Business Administration, 7(1), 130-139.

Raisch, S. 2008. Balanced Structures: Designing Organizations for Profitable Growth. Long Range Planning, http://www.elsevier.com/locate/lrp.

Robbins, S.P. 1990. Organization theory. Prentice-Hall, New York.

Shetty, Y.K. 1979. New look at corporate goals. California Management Review, 16, 2, 71 79.

Sovizdranyuk, A.V., Chigidin, O.D. 2016. Integration and expansion of retail formats in the retail system. Prospects for the development of entrepreneurship in the countries of the Eurasian Economic Union: proceedings of the international scientific-practical conference. Crimean Institute of Business, Simferopol, 204-206.

Trefilova, I.N., Prokoptsov, V.E. 2015. The evolution of chains and the creation of networks of value. Innovation Science, 12, 291-295.

Usenko, L.N., Bogataya, I.N., Bukhov, N.V., Kuvaldina, T.B., Pavlyuk, A.V. 2018. Formation of an integrated accounting and analytical management system for value analysis purposes. European Research Studies Journal, 21(Special Issue 1), 63-71.

Walas-Trębacz, J. 2015. Management instruments used in the field of competitiveness. ECONOMICA, 2, 61, 39-53.

Walton, E.J., Dawson, S. 2001. Managers' perception of criteria of organizational effectiveness. Journal of Management Studies, 38, 2, 173-199.

Yuldasheva, O.U., Bagiev, G.L., Prokoptsov, V.E. 2013. Strategic networks - modern organizational forms of joint enterprise and building value chains. Bulletin of St. Petersburg State University of Economics, 2(80), 49-55.

Znatov, E.A. 2007. Development Strategy for Network Trade Organizations. Ph.D., thesis, Moscow, 24. 